\title{
LITTER DECOMPOSITION IN Rhizophora sp. MANGROVE STANDS OF VARYING PLANTING AGES
}

\author{
Anang Kadarsah ${ }^{1}$ \\ 1Department of Biology, Faculty of Mathematics and Natural Sciences, Lambung Mangkurat \\ University. JI.A. Yani Km 35.8 South Kalimantan, Indonesia. Tel./Fax. +62-511-4773112, \\ email : anangkadarsah@gmail.com
}

\begin{abstract}
Information about litter decomposition in Rhizophora Sp. mangrove stands of different planting ages is very important to find out the main factors affecting the whole information on structure and function of mangrove ecosystem and to improve mangrove management in the future. The objective of this study was to determine the litter decomposition in Rhizophora sp. mangrove stands of varying planting ages, with a case study in Subang Regency, West Java Province. Comparisons of litter decomposition were taken from five stands of planting ages (4 years, 12 years, 21 years, 29 years, and 38 years old). Four parameters of litter decomposition compared were dry weight of litter, decomposition rate, litter decomposition coefficient, and half-life time. The observation on Rhizophora Sp. mangrove stands was conducted in three plots of $10 \mathrm{~m} \times 10 \mathrm{~m}$. The results show that the litter decomposition parameters, especially dry weight of litter, decomposition rate, litter decomposition coefficient, and halflife time, were different on each planting age of Rhizophora sp. mangrove stands. The fastest time for litter decomposition was found in 12 years old of Rhizophora Sp. stands with the achievement for 90 days of observation and the decomposition efficiency of $100 \%$. Meanwhile, the slowest was found in 38 years old of Rhizophora Sp. mangrove stands with more than 120 days, and the litter decomposition efficiency was about 97.84\%. Environmental conditions (soil and water conditions, nitrogen content, and soil fauna) play a major role on its differentiation. It can be concluded that the litter decomposition in Rhizophora sp. mangrove stands of varying planting ages change over time because of the environmental conditions, but the complexity of the relation between ages is not always apparent.
\end{abstract}

Keywords: litter, decomposition, mangrove, Rhizophora.

\section{INTRODUCTION}

Changes in the structure and function are characteristics of ecosystem dynamics (Myster, 2001) due to fluctuations in environment and activities of organisms on time scales ranging from microseconds to millions of years (Chapin et al, 2002). The dynamics of ecosystem structure and function over time determine the characteristics of the ecosystems (Field, 1998) and impact directly to the human beings (Begon et al, 2006). Decomposition is one of the main fundamental ecosystem function that converts organic materials into inorganic nutrients and $\mathrm{CO} 2$ (Chapin et al, 2002), and then releases the energy as a result (Mason, 1976). It is inevitable that the sustainability of recycling materials and other essential ecological processes depend entirely on the process of decomposition (Adl, 2003), to ensure the continuity of supply of organic matter and nutrients in ecosystems (Fonte and Schowalter, 2004).

In the mangrove ecosystem, nutrients from the decomposition process are the useful addition of vegetation growth, and also a source of food in detritus form for aquatic organisms in marine and estuarine ecosystems (Alongi, 2009). The existing assumption is that the structure and function will change with the age of the ecosystem.

Rhizophora Sp. is a kind of mangrove ecosystem plants found in Indonesia including in Java and Kalimantan. Several studies on vegetation structure have been widely exposed, but only a few studies discuss about litter decomposition in mangrove ecosystems dominated by Rhizophora Sp. This study is needed in efforts to find out the main factors in improving the successful management of mangrove (Ashton et al, 2003) and keeping it from various pressures and anthropogenic activities (Chapin, 2002). The important 
question considered from this study is how the mechanism of litter decomposition in Rhizophora Sp. mangrove stands can change in line with the age of planting.

\section{MATERIALS AND METHODS}

\section{Study area}

This study was conducted in the ecosystem of Rhizophora sp. mangrove of varying planting ages from June to October

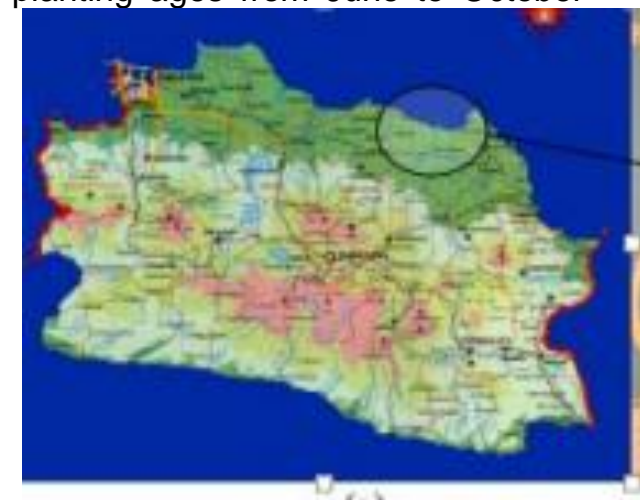

(a)
2011. As a case study, the sampling site was the mangrove ecosystem managed by $\mathrm{RPH}$ (Resort Stakeholder of Forest) Poponcol in Subang Regency, West Java Province (Figure 1). There were five types of vegetations found, based on its ages $(4,12$, 21,29 , and 38 years old). The parameters of litter decomposition were the litter dry weight on the $\mathrm{n}$-th day, decomposition rate, constants, and half-life.

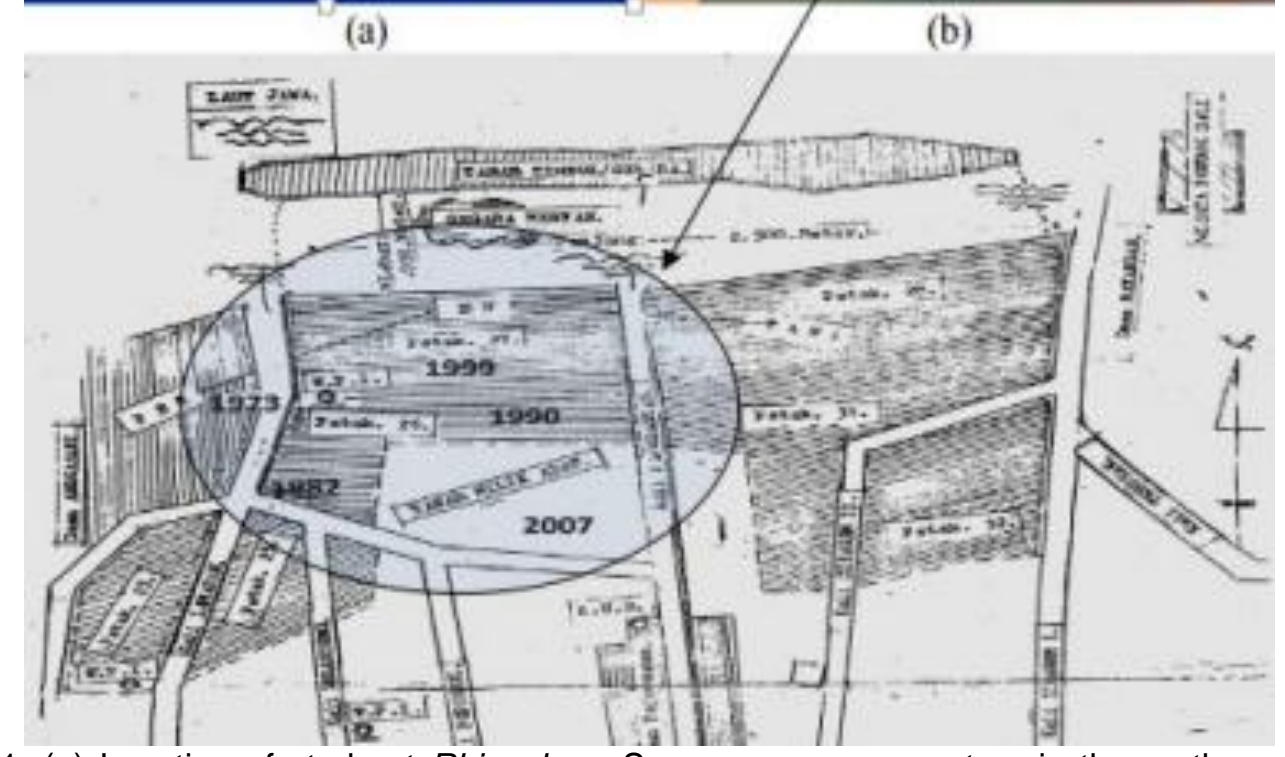

Figure 1. (a) Location of study at Rhizophora Sp. mangrove ecosystem in the northern coast of West Java. (b) Potected forest area belonging to BKPH Ciasem Pamanukan and managed by RPH Poponcol, Subang.

\section{PROCEDURES}

\section{Litter decomposition experiments}

Three bags of litter were quickly moved into the forest floor for each group of planting ages. Each bag was tied to a Rhizophora sp. mangrove stand, so that it would not be carried away by tide. The litter bag was made in a rectangle form with a size of $20 \mathrm{~cm} \times 30 \mathrm{~cm}$ as shown in Figure 2. The materials of litter bags were nylon gauze pads with a size of $>7 \mathrm{~mm}$ for easy entries of micro-invertebrate decomposers (Mason, 1976). 


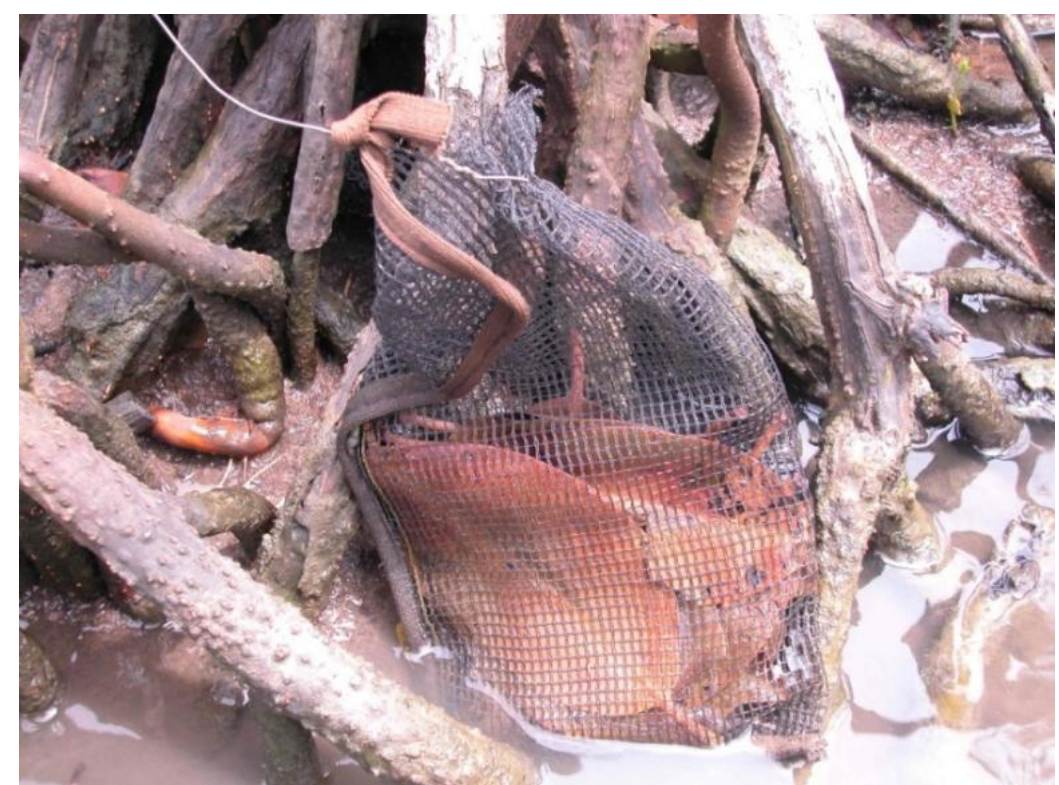

Figure 2. Placement of litter bag on the forest floor of Rhizophora Sp. mangrove stands.

Fresh litters (fallen leaves) from Rhizophora Sp. mangrove stands were collected as the experimental materials, and then incorporated into the litter bag with the size of $20 \mathrm{~cm} \times 30 \mathrm{~cm}$. Before it, the litters were weighed with each weighing about 100 grams. The litters were then put into bags and placed in every Rhizophora Sp. stand based on planting age criteria. The total number of litter bags made in this experiment was 50 bags. The observations were carried out over a 120 day period with the collecting interval every 15 days. In each sampling, the collected litter was brought to the laboratory and dried in the dryer with 60 Celsius degree of temperature for seven days until its weight was constant.

\section{Measure of litter decomposition parameters}

The parameters measured in the litter decomposition were the final weight on the $\mathrm{n}$ th day, decomposition rate, constants, and the half-life. The estimation of litter decomposition coefficient values was obtained using the formula $X t=X o \cdot e^{-K t}$ : where $\mathrm{Xt}=$ litter dry weight after an observation time of day $t$ (in grams), Xo = initial litter dry weight (in grams), $\mathrm{e}=$ natural logarithm (2.72) , K = coefficient of litter decomposition (day-1), and $t=$ observation time (day).

The time required for litter decomposition to become a half of parts (half-life $=t 50$ ) using the formula $t 50=\ln 2 / K$ (Ashton et al, 1999). The percentage of litter decomposition was calculated using the formula $^{Y=\frac{X o-X t}{X t} \times 100}$, where $\mathrm{Y}=$ the percentage of decomposed leaf litter, $\mathrm{X}_{\mathrm{o}}=$ early dry weight of litter (in grams), and Xt = final dry weight of litter after the observation time (in grams) (Boonruang 1984 in Lestarina, 2011).

\section{Enviromental Conditions in Rhizophora Sp. mangrove stands}

The measurement of the environmental conditions (light intensity, humidity, and air temperature) was carried out in the morning every time the samples were taken. The repetition for sampling was performed about three times for each study site and the average was calculated.

\section{RESULTS AND DISCUSSION}

1. Dry weight of litter in Rhizophora Sp. mangrove stands of varying planting ages

Based on the dry weight calculation of litter (Figure 3) it was found out that the litter decomposition was related with Rhizophora sp. mangrove stands of planting ages. The fastest litter decomposition was achieved on 90 days of observation in 12 years old of Rhizophora Sp. stands with completed decomposition (100\%). The litter decomposition of 38 years old of Rhizophora Sp. mangrove stands took the slowest time, more than 120 days, and was also achieved only about $\mathbf{9 7 . 8 4 \%}$ for litter decomposition. 


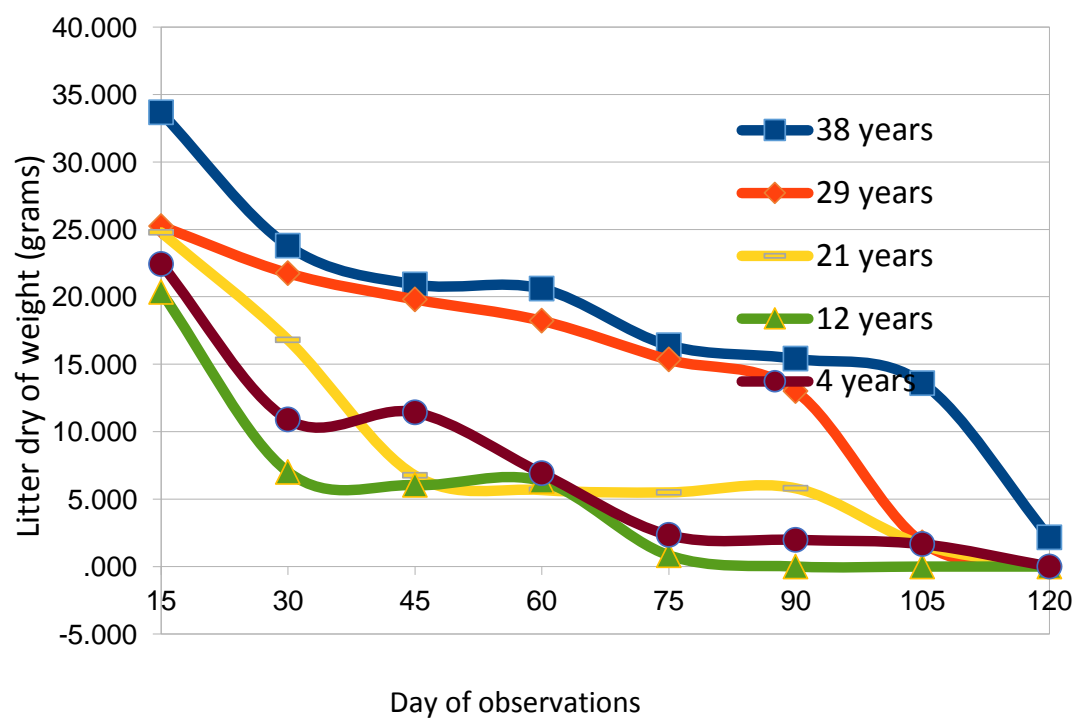

Figure 3. Dry weight of litter ratio in Rhizophora Sp. mangrove stands of varying planting ages

2. Decomposition rate in Rhizophora Sp. mangrove stands of varying planting ages

The results showed that all of Rhizophora sp. mangrove stands achieved the highest litter decomposition rate in the first 15 days (Table 1). The fastest decomposition rate occurred in 12 years old ( $5.31 \mathrm{~g}$ day- 1$)$, and 38 years old ( $4.42 \mathrm{~g}$ day1. The results of 30th day observation and beyond showed that the decomposition rate was slower in of Rhizophora sp. mangrove stands.

Table 1. Litter decomposition rate in Rhizophora sp. Mangrove stands of varying planting ages.

\begin{tabular}{llllll}
\hline \multirow{2}{*}{ Observation at day } & \multicolumn{5}{c}{ Litter decomposition rate(gram days-1) } \\
\cline { 2 - 6 } & 4 & 12 & 21 & 29 & 38 \\
\hline 15 & 5.17 & 5.31 & 5.01 & 4.98 & 4.42 \\
30 & 2.97 & 3.1 & 2.77 & 2.61 & 2.54 \\
45 & 1.97 & 2.09 & 1.78 & 1.78 & 1.76 \\
60 & 1.55 & 1.56 & 1.57 & 1.36 & 1.32 \\
75 & 1.3 & 1.32 & 1.26 & 1.13 & 1.11 \\
90 & 1.09 & 0 & 1.05 & 0.97 & 0.94 \\
105 & 0.94 & 0 & 0.94 & 0.94 & 0.82 \\
120 & 0 & 0 & 0 & 0 & 0.82 \\
\hline
\end{tabular}

3. Litter decomposition coefficient in Rhizophora Sp. mangrove of varying planting ages

Like the rate of decomposition, the highest decomposition coefficient value is obtained in the first 15 days (Table 2). The higher coefficient value also indicates a relatively high rate of decomposition. In this study, the highest coefficient was obtained on 12-years old of Rhizophora Sp. mangrove stand $(0.11)$ and the lowest on 38 years old (0.07). 
Table 2. Litter decomposition coefficient in Rhizophora sp. mangrove stands of varying planting ages

\begin{tabular}{llllll}
\hline \multirow{2}{*}{ Observation at day } & \multicolumn{5}{c}{ Average of litter decomposition coefficient $(\mathrm{k})$} \\
\cline { 2 - 6 } & 4 & 12 & 21 & 29 & 38 \\
\hline 15 & 0.1 & 0.11 & 0.09 & 0.09 & 0.07 \\
30 & 0.07 & 0.09 & 0.06 & 0.05 & 0.05 \\
45 & 0.05 & 0.06 & 0.06 & 0.04 & 0.03 \\
60 & 0.04 & 0.05 & 0.05 & 0.03 & 0.03 \\
75 & 0.05 & 0.06 & 0.04 & 0.03 & 0.02 \\
90 & 0.04 & 0 & 0.03 & 0.02 & 0.02 \\
105 & 0.04 & 0 & 0.04 & 0.04 & 0.02 \\
120 & 0 & 0 & 0 & 0 & 0.03 \\
\hline
\end{tabular}

\section{Half-life decomposition in Rhizophora} Sp. mangrove stands of varying planting ages

The half-life of litter decomposition in Rhizophora sp. mangrove stands does not show a specific pattern with age of planting. Figure 4 shows that the fastest half-life was on the stands aged 12 years old $(10.86$ days), followed by the stands aged 21 years (17.6 days), stands aged 4 years (17.75 days), stands aged 29 years ( 18.04 days) and the longest was the stands aged 38 years old (21.68 days).

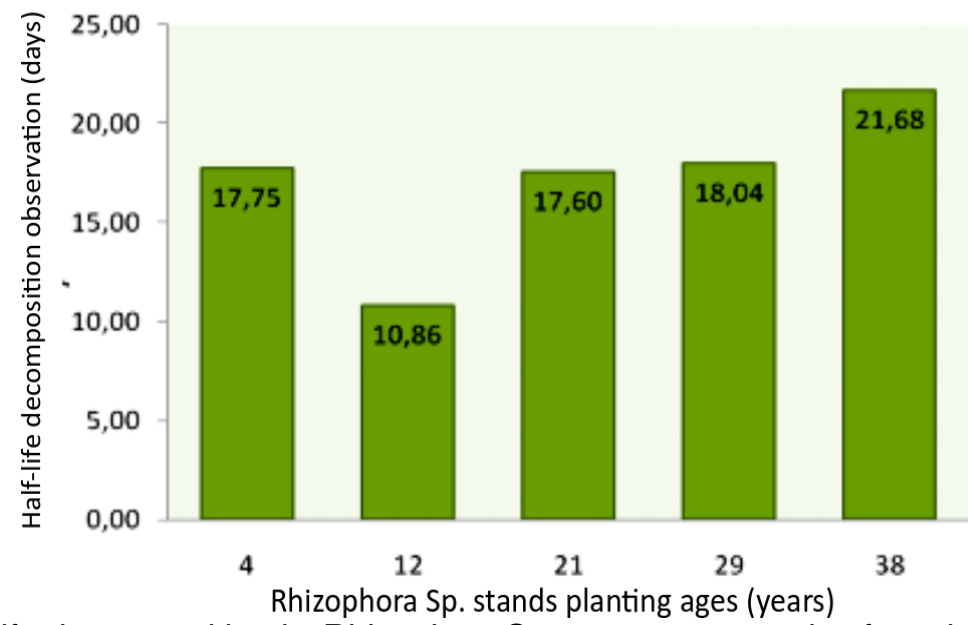

Figure 4. Half-life decomposition in Rhizophora Sp. mangrove stands of varying planting ages

\section{Environmental Conditions in Rhizophora Sp. mangrove stands of varying planting ages}

The measurement of environmental conditions (light intensity, air temperature and air humidity) in Rhizophora sp. mangrove stands of varying planting ages is shown in Table 3. The measurement of the environmental conditions has a range of relatively equal values at a certain observation day. Through one-way ANOVA analysis, it was found out that the air temperature and humidity condition among the planting ages of Rhizophora Sp. mangrove stands did not differ $(P>0.05)$; meanwhile, the light intensity among the planting ages of the stands indicated a difference $(P<0.05)$.

Table 3. Environmental conditions in Rhizophora mangrove stands of varying planting ages

\begin{tabular}{llccccc}
\hline \multirow{2}{*}{ No } & \multicolumn{2}{c}{ Parameter } & \multicolumn{4}{c}{ Ages of Rhizophora sp. Mangrove (years) } \\
\cline { 2 - 6 } & & 4 & 12 & 21 & 29 & 38 \\
\hline 1 & Light Intensity $($ Lux $)$ & \pm 5840 & $\pm 5594,6$ & $\pm 55970,8$ & $\pm 5581,8$ & $\pm 54819,3$ \\
\hline 2 & Air Temperature $\left({ }^{\circ} \mathrm{C}\right)$ & $\pm 28,9$ & $\pm 28,3$ & $\pm 28,6$ & $\pm 28,1$ & $\pm 27,9$ \\
\hline 3 & Air Humidity $(\%)$ & $\pm 87,5$ & $\pm 85,5$ & $\pm 84,3$ & $\pm 85,4$ & \pm 86 \\
\hline
\end{tabular}




\section{DISCUSSION}

1. Litter decomposition in Rhizophora Sp. mangrove stands of varying planting ages

To find out the litter decomposition in every planting ages of Rhizophora sp. mangrove stands, the Tests of Between-

Subjects Effects was used and a significance value for $0.015(P<0.05)$ was obtained. It can then be concluded that there are some differences on litter decomposition in each planting ages of Rhizophora sp. mangrove stands.

The differences on litter decomposition mentioned above occurred only when the litter was placed and then decomposed for a release time in Rhizophora sp. stands of mangrove. The leaves are the component supporting the canopy of a tree, which temporarily and relatively short-live. Although only a small part of biomass for making up the canopy, the leaves have a high nutrient content and quickly turn into litter (Fonte and Schowalter, 2004).

\section{Half-time decomposition in Rhizophora} $\mathrm{Sp}$. mangrove stands of varying planting ages

According to Mason (1976), on the first month the litter will lose in weight quickly and the nutrients it contains will dissolve into soil through leaching. The measurement of weight loss is useful to find out the morphological changes of various large and complex networks into small particles (Mason, 1976). In general, the pattern of weight (biomass) is a result of the litter decomposition followed by the shape transformation of exponential decay curve. Therefore, the decomposition rate can be calculated as the time taken by half of certain mass, or half-life (Hogart, 2007). On a study, the half-life of Avicennia leaves that are always submerged is only 11-20 days, while in the tidal area it may reach more than 90 days. The decomposition levels may also vary for each vegetation type (Robertson et al., 1992 in Hogart, 2007).

\section{Environmental Conditions in Rhizophora Sp. mangrove stands of varying planting ages}

Environmental conditions play a major role in the litter decomposition in Rhizophora sp. mangrove stands. The evidence shows the soil condition parameters, especially on the stagnant water conditions, the nitrogen content in forest floor, and the presence of soil fauna. Water logging assists organisms to activate in outlining the organic materials (Mason (1976). According to Hogart (2007) the litter that inundates rivers for some time will decompose faster. Based on the performance, the Rhizophora sp. mangrove stands from 4 years old to 21 years old are frequently inundated by water so the decomposition occurs more rapidly. Unlike the older stands ( 29 and 38 years old), the sedimentation in their roots helps the forest floor dry faster when the water is receding, thus slows down the litter decomposition.

Decomposition can be influenced by nutritional status in the environment (Lavelle et al., 1993 in Fonte and Schowalter, 2004), but the nutritional content of the litter decomposition is also limited by the presence of the essential elements (mostly limited by nitrogen or phosphorus) (Boddy and Watkinson, 1995 in Fonte and Schowalter, 2004). The litter decomposition occurs faster when the nitrogen content is higher than before (Chapin et al, 2002). The measurements of Rhizophora sp. mangrove soil showed that the 12 year stands with highest nitrogen content (0.34\%) experienced fastest decomposition, but the 38-year stands experienced slowest decomposition because the nitrogen content was lower (only $0.29 \%$ ).

Groups of decomposer faunas play a very important function of decomposition (Killham, 1994 in Fonte and Schowalter, 2004). In coastal habitats, the potential decomposer faunas are Polychaeta, Amphipoda, and molluscs (gastropods and bivalves) (Mason, 1976). The observation on the decomposer faunas in Rhizophora sp. mangrove stands of varying planting ages was conducted at the 15th daytime of observation. Although not recorded in detail, it was found that the dominant decomposers were small shrimp Gammarus sp. (Amphipoda), water insect (Thysanura), and sesarmid crab.

\section{CONCLUSION}

1. There are some differences on litter decomposition in every planting age of Rhizophora sp. mangrove stands, based on three main parameters, namely dry weight of litter, decomposition rate, litter decomposition coefficient, and half-life time. 
2. Environmental conditions play a major role in the litter decomposition in Rhizophora sp. mangrove stands, especially for the soil condition parameters, water conditions, nitrogen content in forest floor, and the presence of soil fauna.

3. It can be concluded that the regulation function parameters, especially the litter decomposition in Rhizophora sp. mangrove stands of varying planting ages can change over time, but the complexity of relations between ages is not always apparent and depends on the environmental conditions.

\section{REFERENCES}

Adl, S.M. (2003). The Ecology of Soil Decomposition. CAB Publishing, Cambridge.

Alongi, D.M. (2009). Paradigm Shifts in Mangrove Biology. Chapter 22. In Coastal Wetlands. An Integrated Ecosystem Approach. Edited by Perillo,G.M.E., E.Wolanski, D.R.Cahoon, and M.M. Brinson. Elsevier, B.V.

Ashton, E.C., P.J. Hogarth, and R. Ormond. (1999). Breakdown of Mangrove Leaf Litter in A Managed Mangrove Forest in Peninsular Malaysia. Hydrobiologia. 413: 77-88.

Begon, M., C.R. Townsend, and J.L. Harper. (2006). Ecology: From Individuals to Ecosystems. Fourth edition. Blackwell Publishing Ltd, Oxford.

Chapin III, F.S., Matson, P.A., and Mooney, H.A. (2002). Principles of Terrestrial Ecosystem Ecology. SpringerVerlag, New York.

Field, C. D. (1998). Rehabilitation of Mangrove Ecosystems: An Overview. Marine Pollution Bulletin Vol. 37, No. $8 \pm 12$, pp. $383 \pm 392$. Elsevier Science Ltd.

Fonte, S.J., dan T.D. Schowalter. (2004). Decomposition in Forest Canopies. Chapter 21. Page 413-420 in Forest Canopies. Second Edition. Edited by Margaret D. Lowman and $\mathrm{H}$. Bruce Rinker. Elsevier Academic Press, Tokyo.

Hogart. P. (2007). The Biology of Mangroves and Seagrasses. Oxford University Press, New York.
Mason, C.F. (1976). Decomposition. The Institute of Biology's. Studies in Biology no. 74. Edward Arnold (Publishers) Limited, London.

Myster. 2001. What is Ecosystem Structure? Caribbean Journal of Science, Vol. 37, No. 1-2, 132-134, 2001. Copyright College of Arts and Sciences, University of Puerto Rico, Mayagu"ez. 